\title{
Research on Translated Text of Makhioui in Simalungun Wedding Ceremony into Indonesia Language
}

\author{
Rohdearni Wati Sipayung ${ }^{1,4}$, Abdurahman Adisaputera ${ }^{2}$, Amrin Saragih $^{2}$, Roswita Silalahi ${ }^{3}$, \\ Syahron Lubis ${ }^{3}$
}

${ }^{1}$ Linguistics Department, Faculty of Cultural Studies, North Sumatera University (USU), Medan, Indonesia

${ }^{2}$ Faculty of Language, Department of English Language, State University of Medan (UNIMED), Medan, Indonesia

${ }^{3}$ Faculty of Cultural Studies, English Department, North Sumatera University (USU), Medan, Indonesia

${ }^{4}$ English Department, Faculty of Language, Simalungun University (USI), Medan, Indonesia

Email address:

ahmedalbukhary@yahoo.com (R. W. Sipayung), bukharyahmedal@gmail.com (A. Adisaputera)

\section{To cite this article:}

Rohdearni Wati Sipayung, Amrin Saragih, Rahman Adisaputera, Roswita Silalahi, Syahron Lubis. Research on Translated Text of Makhioui in Simalungun Wedding Ceremony into Indonesia Language. International Journal of Language and Linguistics.

Vol. 4, No. 1, 2016, pp. 30-39. doi: 10.11648/j.ij11.20160401.15

\begin{abstract}
The research objective is to formulate the procedures applied by translators in translating Makhiou text on Simalungun wedding ceremony Indonesian language and assess the impact of translation procedure on the quality of translation in terms of accuracy, acceptability and readability. The method used in this research is oriented on the product or the work of translation. Translation unit is examined at the level of the sentence. The translation unit is set so that the study can be done in detail. It can be used as the basis to establish the conclusions of the study. This research uses the descriptivequalitative approach because it is a verbal text which is translated into written.
\end{abstract}

Keywords: Translation, Procedure, Makhioui, Umpasa, Accuracy, Acceptability, Legibility

\section{Introduction}

Indonesia is a rich and multicultural country. Indonesia has 34 provinces and 1,128 ethnic groups where each tribe has its diversity. Culture is a very valuable asset that can be used as the basic capital in building and developing it. It means that the presence of our culture can be known and coexisted.

By culture, we can find out the identity and image of humans, either individual, groups, organizations or specific communities. But unfortunately, this diverse and beautiful country is not widely known to the outside because of the language barrier. In this era of globalization, the intensity of communication among countries are increasingly high. It is not enough when science and technology are absorbed from developed countries by means of translation. This rich culture of Indonesia can be introduced to some countries through the translation so that the country is better known and attracts the attention of other nations, which in turn will attract foreign tourists to visit Indonesia.

Simalungun is one of the Batak tribe in North Sumatra. Just like other Batak, Simalungun has its customary in every ceremony. One of the aspects of traditional culture is implementation of specific Simalungun marriage. Informal interview conducted in Simalungun shows that the wedding is a specific event and has a religious significance for the tribe of Simalungun. This interview shows that the sociocultural implementation in a wedding tradition is an obligation and as a symbol that a married person and his family cultured person. Religiously, implementation is intended to receive the blessings of Almighty God who is believed to be submitted by the parents of the bride along with their families.

Before the traditional party, the first step must be done is a religious wedding blessing. Afterwards, a custom implementation begins with a first party of man to feed bride and then proceed to the relatives of the bride and to his uncle. The next party from the bride's traditional food is handed to the bride as well as the brother of the groom followed by a welcoming ceremony and tribute to those of men and women of high rank in the family by means of dancing together (manortor). It is done alternately between the bridegroom and his family continued with the bride and also her relatives. After the show is done, and then followed by having a meal together. While the meal goes, respecting food (pinggan 
panganan) in the form of "panganan pinatunggung" is distributed each other. After a common meal is finished, the bridegroom hands a demban which is commonly called the "demban salpu mangan" to the bride.

The next event is the delivery of custom fabrics (custom hiou) or called Makhioui from the bride to the groom and his relatives- who deserve it. In addition, there is also a provision in the form of money. And as an expression of thanks, the groom also provides custom fabrics (hiou) and also gives some money to the bride. This traditional event is the end of a traditional wedding ceremony. But first party of the bridegroom and bride give some money to compatriots or to any person who present this traditional event.

In this wedding ceremony, the cloth of Makhioui does not off handed, it must be there are some pieces of advice, discourse, and can also be supplied by some umpasa which is similar to rhymes. Of course, the language is spoken in Simalungun language.

Example:

SL: Sai tubuhan laklakma

Tubuhan tobu

Sai tubuhan anakma

Tubuhan boru

TL: Agar pengantin diberkati Tuhan memperoleh/melahirkan anak laki-laki dan perempuan.

In translation studies, poem presented in a marriage ceremony is regarded as a source language (SL) where its meaning or message can be routed and delivered in target language (TL). The structure of the poem is a form forming composition of poetry. The structure is built by two aspects, namely sampiran and content. Sampiran serves as forming rhyme or tone. Sampiran also is called shadow because in rhyme classic sampiran is sometimes shadow content.

eg:

Berakit-rakit ke hulu

Berenang-renang ke tepian

Bersakit-sakit dahulu

Bersenang-senang kemudian

Berakit-rakit dahulu, berenang-renang ke tepian implicitly describes that one must work hard to achieve something. Then the next line clarifies what is implied in sampiran earlier. "Bersakit-sakit dahulu..." This sentence is explanatory of "berakit-rakit ke hulu." Likewise, umpasa Simalungun, sampiran is not translated yet. It is only imagination of the contents and functions as forming rhyme or tone.

Example:

SL: Tubuhma hayu anak pakon tobu

I buttuni tapian

Sai tubuhma anak pakon boru na jitu-jitu

Na lang panahit-nahitan.

TL: Agar pengantin memperoleh anak laki-laki dan perempuan yang pintar-pintar dan sehat-sehat.

The translation is essentially the process of transfer of ideas / thoughts of author in SL into ideas/thoughts. Therefore, the most important thing in any translation process is how the translation as much as possible diverts the mind of a writer in Simalungun language into the reader's understanding in Indonesian language. The translation is done by a variety of purposes such as the interests of science, conservation and development, commodity interests in the field of tourism, initiate and develop cooperation in the field of culture, and others. Newmark (1981) says that translating is a business that involves a highly complex process. Translating not only diverts SL to TL or just looking for a synonym from one language to another. Translating involves a process of understanding, explaining, analyzing and interpreting even including word processing art. Newmark is known for his theory of semantic translation and communication. He considers that the translation should also be seen as part of communication.

In the cultural translation, it is often found that TL is not same with the SL because of the different concept of culture. It is because of cultural differences between SL into TL. Thus an interpreter will find it difficult when translating text from different culture. This difference will directly put the translator in a position of dilemma. Where, in one side the translator must translate the text of SL into TL accurately and on the other hand, the translator must find the equivalent word of which it does not exist in the target language and in the end this situation led to the emergence of translation. Thus stated Newmark (1988), "Frequently where there is cultural focus, there is a translation problem due to the cultural 'gap' or 'distance' between the source and the target language".

This uncommon situation is interested in the author in reviewing the text of Makhioui in Simalungun traditional wedding ceremony to Indonesia language into an article so that Simalungun people who live in other places can understand the way of wedding ceremony especially Makhioui and other communities who is outside from Batak tribe in Simalungun is interested in knowing this custom. Because of the development world, there are many Batak Simalungun ethnic communities do not live in Simalungun again or migrate. Their children no longer know Simalungun tradition, even Simalungun language.

\section{Theoretical Review}

Makhioui is a process or activity giving hiou /mambere hiou as a symbol giving warm and affection to the recipient of hiou. Just like the other tribes in the surrounding areas, tribal Simalungun clothing worn at the wedding cannot be separated from the use of fabric. Simalungun Batak tribal fabric called hiou. Hiou is originally synonymous with ajimat (magic), believed to contain the "strength" of a religious nature magical and sacred and has a special power to provide protection.

In legend, hiou is regarded as one of the three sources of warm for humans (besides the fire and the sun), but it is seen as the most convenient source of warm because it can be used anytime and anywhere, unlike the sun, and cannot be burnt (like fire). Like the other tribes in Batak, Batak Simalungun has a habit of "mambere hiou" (giving hiou). Hiou can be worn in various forms, as the cloth covering the head, covering the bottom of the body, upper body cover, 
back cover and others.

Hiou in various shapes and patterns/motifs has some names and types, for example hiou to cover the head of a lady is called suri-suri, hiou which covers the bottom of the woman's body is called ragi panei or used as everyday clothing called jabit. Hiou in wedding ceremony is symbolized as a kinship of Simalungun called tolu sahundulan, which consists of headgear (headband), breastplate (clothing) and closed bottom (abit).

\section{Method of Research}

To produce innovative research, a lot of things should be done such as preparing the first step, the process until the writing of the research results. The series of these activities are the key to success in a study. In other words, the research plan, the process of research and writing research results should be the main focus of research. Various stages in the research, we need to look from the idea of the study, the type of research that we choose, the samples taken, the process of collecting data, analyzing the data during the research process, the method of analyzing the data to the decision and finally the conclusion of the study.

This research is oriented on the product or the work of translation. Translation unit is examined at the level of the sentence. The translation unit is set so that the study can be done in detail. It can be used as the basis to establish the conclusions of the study. This research uses the descriptive qualitative approach because it is a verbal text which is translated into written form. Qualitative research produces descriptive data in the form of words written or spoken about people or behaviors that can be observed. Qualitative data is data in the form of words, not in the form of numbers (MONE, 2008). Qualitative research generally takes smaller samples, and tends to choose the purposive rather than random.

Descriptive-qualitative research uses a qualitative data in the form of a sentence. The use of qualitative descriptive method aims to create a description, picture, or painting in systematic, factual and accurate information on the facts, nature and the relationship between the phenomena investigated qualitatively. In this section, we discuss the components applied in research methods, such as study design, data and sources of research data, the object of research, technique collecting data and technique analyzing data.

\subsection{Data Sources}

The data source can be obtained from the data subject. The researcher uses a questionnaire or interview in collecting data, then the data source of the respondent, the person who answered the question namely written or oral. Sources of data in qualitative research can be a human being, event or activity, place or location, objects, various photographs, and recordings, as well as documents and archives (in Silalahi, 2009).

\subsubsection{The Data Source of This Research Is as Follow}

a. A Textbook "Book of Uppasa Pakon Uppamani Simelungun" written by Drs. Salmon Sinaga, in 2010 consisting of 71 terms.

This book contains Umpassa Simalungun, Purpose of Uppama Simalungun and Its Meaning, Motto of Simalungun and Pematangsiantar, Passion/Spirit of Doding $\mathrm{Na}$ ambangkithon Simalungun and Doding Simalungun. In this study, researcher subtitles only take 12 and 19. Sub title 12 by 7 Umpassa Source Text and target text as much as 7 and consists of 2 pages, 19 texts subtitles as much as 8 Umpassa Source and target text 8 and consists of 1 page. This poem consists of 15 Umpassa.

b. Appraisal

In determining the level of translation accuracy assessment in the study, it is conducted by researcher herself because she is Simalungun people and knows much both languages (Simalungun and Indonesia) and its cultures.

\subsubsection{The Informants}

Informant is involved to determine the level of acceptability and legibility translation. As for the key informants, in this study, are: Fariaman Purba SE., M. Si, Liharman Saragih SE., M. Si and Ir. Marlindoaman Saragih., Pd.

a All informants are a member of DPD Partuha Maujana Simalungun (PMS) which know much about historical and cultural Simalungun on Simalungun district.

b The positions of all informants are as Syamas (Sy) for 20 years in GKPS (Protestant Church Simalungun). GKPS is the only church using Simalungun language as the language of instruction in the ritual.

c All informants is also lecturers at the university who have high abilities.

\subsection{Objectives of This Research}

This study has two objectives, the event text language and meaning of the text transfer language events from the source language to the target language. Text language event is Makhioui in the wedding party held in Simalungun tradition in Pematangsiantar. The reason for choosing this area; it is still used by the people with all of Simalungun tradition/culture including wedding event. The transfer of the meaning of the SL text to TL is to shift the meaning of the text Makhioui in the wedding party held in Simalungun, Indonesian.

\subsection{Techniques of Data Collection}

a Analysis of the documentation (content analysis).

Data collection method in this research is the analysis of the documentation that is by reviewing documents and archives or read and record the techniques derived from the "Book Uppasa Pakon Uppamani Simalungun" and its translation into Indonesian. Researcher collects data from the book in the form of words, phrases, and sentences that are presented in the table. This technique is applied to collect data related to the translation procedure.

b Questionnaire (questionnaire).

This technique is used to collect data about the quality of translation, which includes three things: the level of accuracy, the level of acceptance and readability level. Researcher uses 
a scale of 1-3). To measure the level of quality of the translation is used measurement instrument table. This study uses three questionnaires namely Accuracy Rating Instrument to determine the level of equivalent translation. Rating acceptability instrument is used to measure the level of acceptability of the level of translation. Readability rating instrument is used to measure the readability level of translation.

Each of the three questionnaires is based on a scale of assessment as it is displayed on this table.

Table 1. Measure the Accuracy of Translation.

\begin{tabular}{lll}
\hline Scale & Definition & Conclusion \\
\hline 3 & $\begin{array}{l}\text { The meaning of the text, technical terms, phrases, } \\
\text { clauses or sentences is accurately transferred } \\
\text { from source language into the target language; }\end{array}$ & Accurate \\
& $\begin{array}{l}\text { Most of the meaning of texts, technical terms, } \\
\text { phrases, clauses or sentences from the source }\end{array}$ & \\
& $\begin{array}{l}\text { language has been transferred accurately into the } \\
\text { target language. However, there is still a } \\
\text { distortion of meaning or translation of double } \\
\text { meaning or no meaning is eliminated, which } \\
\text { disrupts the integrity of the message. }\end{array}$ & Less \\
& $\begin{array}{l}\text { Meaning of the text, technical terms, phrase, } \\
\text { clause or sentence from the source language is } \\
\text { inaccurately transferred to the target language. }\end{array}$ & No accurate \\
\hline
\end{tabular}

Source: Silalahi (2009) with some modification

Measuring the instrument of the accuracy of the translation adheres to a scale of 1 to 3 . The higher score given by the key informants, the more accurate of translation will result. Conversely, the lower score given by the key informants, the lower of the accuracy level of the translation will be resulted.

Table 2. Instrument Used to Measure the Acceptability of Translation.

\begin{tabular}{lll}
\hline Scale & Definition & conclusion \\
\hline & $\begin{array}{l}\text { Natural translation; the technical term is used } \\
\text { commonly in the field of literature and it is } \\
\text { familiar to the reader. Phrases, clauses and }\end{array}$ & Acceptable \\
& sentences used are in accordance with the rules of \\
& Indonesia language. \\
& In general, the translation already feels natural; but \\
& there is a little problem in the use of technical & \\
& terms or there is grammatical errors occurred & Less \\
& slightly. & acceptable \\
& Translation is unnatural or feels like a work of & \\
& translation; technical terms used are not commonly \\
& used in the field of literature and it is not familiar \\
to the reader. Phrases, clauses and sentences used & No \\
& do not conform to the rules of Indonesia language. & \\
&
\end{tabular}

Source: Nababan (2004) in Silalahi’s Book (2009)

Measuring instrument of acceptability of translation is a guidance of key informants in determining the level of acceptability of the translation. Each score given is a reflection of the level of acceptability of the translation.

As mentioned previously, the third instrument used is the instrument that will be used by the respondent in determining the level of legibility translation, which is also based on a scale of 1 to 3 .
Table 3. Instrument Used to Measure the Readability of Translation.

\begin{tabular}{|c|c|c|}
\hline Scale & Definition & conclusion \\
\hline 3 & $\begin{array}{l}\text { The text, a technical term, phrase, clause, } \\
\text { and sentence translation can be easily } \\
\text { understood by the reader. }\end{array}$ & High Readability \\
\hline 2 & $\begin{array}{l}\text { In general, the translation can be understood } \\
\text { by the reader; however there are certain parts } \\
\text { that should be read more than once to } \\
\text { understand the translation. }\end{array}$ & $\begin{array}{l}\text { Medium } \\
\text { Readability }\end{array}$ \\
\hline 1 & $\begin{array}{l}\text { The translation is found difficult to } \\
\text { understand by readers }\end{array}$ & Low Readability \\
\hline
\end{tabular}

Source: Silalahi (2009) with modification

\subsection{Technique of Data Analysis}

Data analysis techniques in this study include observational data transcription text of Makhioui in the wedding party of Batak Simalungun in Indonesian. Text translation analysis techniques are performed by translating the theoretical framework that has been developed.

In the data collection, research activities are as follows:

1. Reading subtitles Umpassa Makhioui Hubani bride and translation in Indonesian as a whole

2. Underlying its word, phrase and sentence in subtitles Umpasa Makhioui Hubani bride and also its equivalent in Indonesia.

3. Writing sections of text that is underlined in the data table.

4. Identifying and classifying words, phrases, and sentences then carried out assessing the quality of the translation.

To analyze the data, the stage of analyzing used is summarized in the following schematic form.

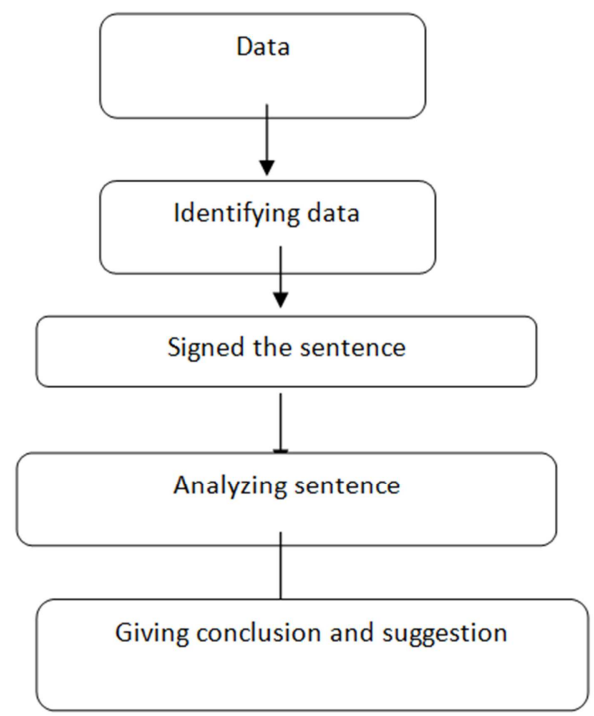

Figure 1. Analyzing Data Process.

\subsection{Research Procedure}

Research procedure performed includes the following steps.

1. Establish data sources, data and translation unit to be 
assessed

2. Establish the problem and research objectives.

3. Comparing the SL text and the translated text to identify what the translation procedures are applied.

4. Assessing the tendency of translation procedures applied.

5. Reviewing the response of key informants to determine the level of accuracy and acceptability of the translation.

6. Assess the responder to determine the level of legibility translation.

7. Integrating the accuracy and level of acceptance with the readability level to reveal the quality of the translation.

8. Drawing conclusions and suggested research and research implications.

\section{Discussion}

\section{Exposure data and research findings}

\section{Translating Procedure}

In this study, it is found that the translator is not only using a single translation procedure, it has been found that the data is decoded by using a combination of translation procedure, namely the translation procedure that uses two translation procedures are called couplets and four translation procedure called quartet procedure.
All data analyzed are totaling 15 data. From all the data, the researcher can identify that there are 11 data using a single procedure, 3 data using couplets procedure, and 1 data using the procedure of quartet.

\subsection{Translating Using a Single Procedure}

Single procedure refers to the application of the procedure alone in translating this research data from Simalungun language into Indonesia language. In this study, it is identified 11 single procedures used by the translator: 1) descriptive translation procedure, 2) transposition, 3) a footnote, and 4) modulation. The data are shown in the following table.

Table 4. Translating Using a Single Procedure.

\begin{tabular}{llll}
\hline Procedure & Variant of single procedure & Number & Persentage \\
\hline Single & (1) Descriptive translation & 5 & $45,5 \%$ \\
& (2) Transposition & 3 & $27,3 \%$ \\
& (3) Footnote & 2 & $18,2 \%$ \\
& (4) Modulation & 1 & $9,0 \%$ \\
\hline
\end{tabular}

i. Descriptive Translation Procedure

\begin{tabular}{|c|c|c|c|c|c|}
\hline & Tubuh & $\mathrm{ma}$ & hayu & pakon & tobu \\
\hline & Lahir & lah & anak laki - laki & dengan & tebu \\
\hline & I & buttuni & tapian & & \\
\hline & Di & atas & tepian, tempat mandi & & \\
\hline \multirow[t]{6}{*}{ SL } & Sai & tubuh & ma anak & pakon & boru \\
\hline & Semoga & lahir & anak laki- laki & dengan & anak perempuan \\
\hline & $\mathrm{Na}$ & jitu-jitu & & & \\
\hline & yang & pintar - pinta & & & \\
\hline & $\mathrm{Na}$ & lang & panahit-nahitan. & & \\
\hline & Yang & tidak & sakit - sakitan/ penyakitan & & \\
\hline
\end{tabular}

The above data translated using descriptive translation procedure (a single procedure) gives the same meaning from SL (Simalungun language).

$S L$ : Sai tubuhma anak pakon boru na jitu jitu

$\mathrm{Na}$ lang panahit nahitan

TL: Agar pengantin memperoleh anak laki-laki dan perempuanyang pintar - pintar dan sehat-sehat.

$S L$ : Na lang panahit nahitan is translated into "sehat-sehat".

ii. Transposition Procedure

\begin{tabular}{clll} 
& Marbuah & ma & gan \\
Berbuah & lah & katanya manga \\
Dalan & \multicolumn{2}{c}{ Bandar Nagori } \\
Jalan & \multicolumn{2}{c}{ Bandar Nagori } \\
SL & Anggo & domma & marrumah tangga \\
& Kalau & sudah & berumah \\
& Ulang & be & tangga/berkeluarga \\
Jangan & lagi & bertengkar/cekcok
\end{tabular}

$T L$ : Dalam rumah tangga janganlah bertengkar.
The data above is translated using transposition procedure (single prosedur).

\section{SL: Anggo domma marrumah tangga}

Ulang be maringori

$T L$ : Dalam rumah tangga janganlah bertengkar.

The above data shown that it is transposition procedure because it changes the long structure becomes a short structure, Anggo domma marrumah tangga Ulang be maringori becomes "dalam rumah tangga janganlah bertengkar".

iii. Footnote Procedure

\begin{tabular}{|c|c|c|c|c|}
\hline \multirow{7}{*}{ SL } & Nasuan & $\mathrm{ma}$ & \multicolumn{2}{|c|}{ timbahou } \\
\hline & Ditanam & lah & tembak & \\
\hline & Dua & gattang & sadari & \\
\hline & Dua & kantongan & sehari & \\
\hline & $\mathrm{Na}$ & ubah & ma & parlahou \\
\hline & Di & rubah & lah & tingkah \\
\hline & $\begin{array}{l}\text { Ulang } \\
\text { Jangan }\end{array}$ & $\begin{array}{l}\text { songon } \\
\text { seperti }\end{array}$ & & $\begin{array}{l}\text { sapari } \\
\text { yang lalu }\end{array}$ \\
\hline
\end{tabular}


$T L$ : Kalau sudah berumah tangga agar perilaku dirobah, jangan lagi

berperilaku lajang.

The above data is translated using the procedure of footnotes (a single procedure). Translator provides information in the form of a footnote to clarify the intended meaning of the translated word because without additional explanation, it is rather difficult for the readers to understand it. It can be seen from the following data:

\section{Bsu: Na ubahma parlahou}

Ulang songon sapari

Bsa: Kalau sudah berumah tangga agar perilaku di rubah, jangan lagi berprilaku

lajang.

The word 'sapari' translated becomes "berprilaku lajang" to add the meaning of 'sapari', because the real meaning of sapari is the last or the past.

iv. Modulation Procedure

$\begin{array}{llll} & \text { Bittang } & \text { na } & \text { rumiris } \\ & \text { Bintang } & \text { yang } & \text { banyak } \\ \text { Ombun } & \text { na } & \text { sumorop } \\ \text { SL } & \text { Embun } & \text { yang } & \text { banyak } \\ & \text { Anak } & \text { pe } & \text { riris } \\ \text { Anak laki - laki } & \text { pun } & \text { banyak } \\ \text { Boru } & \text { pe } & \text { torop } \\ \text { Anak perempuan } & \text { pun } & \text { banyak }\end{array}$

TL: Agar pengantin diberkati Tuhan memperoleh keturunan laki-laki dan perempuan yang banyak.

The above data is translated using the modulation procedure. Translators translate the sentence:

\section{SL: Anak per iris}

Boru pe torop

$T L$ : Agar pengantin diberkati Tuhan memperoleh keturunan laki - laki dan

perempuan yang banyak.

v. Couplets Translating Procedures

Couplet procedure that is a combination of two translation procedures applied in determining the equivalent in the target language. Blend the two procedures in question is a blend of 1) transposition and modulation, 2) additional explanations and modulation, and 3) the descriptive translation and transposition.

Table 5. Couplet Translating Procedure.

\begin{tabular}{ll|l|l}
\hline Procedure & Couplet Variant Procedure & Number & Persentage \\
\hline couplet & $\begin{array}{l}\text { (1) transposition }+ \\
\text { modulation } \\
\text { (2) addition + modulation }\end{array}$ & 1 & $33,3 \%$ \\
\hline $\begin{array}{l}\text { (3) deskriptive translation }+ \\
\text { transposition }\end{array}$ & 1 & $33,3 \%$ \\
& Total & 3 & $33,3 \%$ \\
\hline
\end{tabular}

vi. Transposition + modulation

TL: Agar pengantin diberkati Tuhan memperoleh / melahirkan anak laki- laki

dan perempuan.

\begin{tabular}{|c|c|c|c|}
\hline \multirow{8}{*}{ SL } & Sai & tubuh & laklakma \\
\hline & Semoga & lahir & kulit kayu \\
\hline & Tubuh & $a n$ & tobu \\
\hline & Lahir & lah & tebu \\
\hline & Sai & tubuh an & anakma \\
\hline & Semoga & lahir lah & anak laki - laki \\
\hline & Tubuh & $a n$ & boru \\
\hline & Lahir & lah & anak perempuan \\
\hline
\end{tabular}

The above data is translated using the procedure of transposition + modulation (couplet procedures).

Translation transposition of the above data is shown by the structural changes that occur from SL to TL, namely:

SL: Sai tubuhan anakma

Tubuhan boru

TL: Agar pengantin diberkati Tuhan memperoleh/melahirkan anak laki - laki

dan perempuan.

The sentence structure is $\mathrm{Sai}+\mathrm{P} 1+\mathrm{P} 2+\mathrm{S} 1+\mathrm{S} 2$ be the order $+\mathrm{S} 1+\mathrm{P} 1+\mathrm{P} 2+\mathrm{S} 2+\mathrm{S} 3+$ and $\mathrm{S} 4$.

Then, the application of modulation procedures is indicated on the underlined sentences:

SL: Sai tubuhan anakma

Tubuhan boru

$T L$ : Agar pengantin diberkati Tuhan memperoleh/melahirkan anak laki - laki

dan perempuan.

The underlined sentence, the interpreter gives semantically equivalent different viewpoints meaning or scope of its meaning. But in the context, it gives the same message / the same purpose.

vii. Additional explanation + Modulation

\section{Riahni}

Kesepakatan/kebersamaan

Hotang panakkat

SL Rotan pengikat

Ulang hanami

Jangan kami

Podas

Cepat

parpokkalan
tempat berkumpul,
kedai/warung
para
tempat meletakkan
sesuatu
ngolngolan
tertunggu - tunggu
ma abara
lah bahu

TL: Agar pengantin cepat diberkati Tuhan memperoleh keturunan, jangan sampai orangtua (tondong) lama menanti.

The above data is decoded by using two translation procedures (procedures couplets) that additional explanation (contextual conditioning) + modulation.

Additional explanation procedure (contextual conditioning) is a translation procedure in which the translator gives word (s) specifically to explain SL.

SL: Ulang hanami ngolngolan

Podas martupang ma abara

TL: Agar pengantin cepat diberkati Tuhan memperoleh keturunan, jangan 
sampai orangtua (?) tondong lama menanti.

Kata yang bergaris bawah dibuat untuk menjelaskan Bsa.

Kemudian prosedur modulasi yaitu dimana sudut pandang kalimat kedua "Podas martupang ma abara" menerjemahkan kalimat yang pertama "Ulang hanami ngolngolan".

The underlined word is created to describe TL.

viii. Descriptive Translation + Transposition

$\begin{array}{llll} & \text { Ruttun } & \text { rabing-rabing } \\ & \text { Ditarik } & \text { bernas } & \\ & \text { I } & \text { buttuni tapian } \\ \text { SL } & \text { Di } & \text { diatas tepian, tempat mandi } \\ & \text { Podas } & \text { marabing - abing } \\ \text { Cepat } & \text { memangku } \\ \text { Dapot } & \text { an } \quad \text { passarian } \\ \text { Dapat } & \text { lah } \quad \text { rejeki/penghasilan }\end{array}$

$T L$ : Kiranya pengantin cepat dapat keturunan (anak, boru) dan dapat rejeki /berkat.

The data is translated using descriptive translation + transposition procedure (couplet procedure). Descriptive translation procedure can be seen at the underlined sentence.

SL: Podas marabing abing

Dapotan passarian

$T L$ : Kiranya pengantin cepat dapat keturunan (anak, boru) dan dapat

rejeki/berkat.

In a sentence of SL podas marabing abing can be translated into 'cepat dapat keturunan (anak, boru)'.

Transposition procedure is shown at the change of the sentence structure,

$S L$ : Podas marabing abing

Dapotan passarian

$T L$ : Kiranya pengantin cepat dapat keturunan (anak, boru) dan dapat

rejeki/berkat.

With the structure of SL: Ket $+\mathrm{P} 1+\mathrm{P} 2+\mathrm{S} 1$

Becomes TL: kiranya $+\mathrm{S} 1+\mathrm{P} 1+$ dapat $+\mathrm{S} 2$ dan dapat S3

ix. Translating Quartet Procedures

Quartet procedure is a combination of four translation procedures applied in determining the equivalent in the target language. A blend of four procedures is a

Transposition + descriptive translation + without equivalency + modulation.

Table 6. Translating Quartet Procedure.

\begin{tabular}{llll}
\hline Procedure & Variant Quartet Procedure & Number & Persentage \\
\hline Quartet & $\begin{array}{l}\text { transposition + descriptive } \\
\text { translation + no equivalent }+ \\
\text { modulation }\end{array}$ & 1 & $100 \%$ \\
& Total & 1 & $100 \%$ \\
\hline
\end{tabular}

The table above shows that there is only 1 data from 15 data applied in translation procedure quartet with variant translation procedure that is descriptive translation transposition +++ modulation is not given equivalent. The following description of the variant translation procedure quartets:

\begin{tabular}{|c|c|c|c|c|c|c|}
\hline & Sai & tubuh & & an & lakla & $\mathrm{ma}$ \\
\hline & Semoga & lahir & & lah & kulit & rayu \\
\hline & Tubuh & an & & tobu/sikkor & ng & \\
\hline & Lahir & lah & & tebu/kalung & & \\
\hline & I & dolog & ni & Purba Tua & & \\
\hline & Di & bukit & nya & Purba Tua & & \\
\hline SL & Sai & Tubuh & an & anak . & $\mathrm{ma}$ & Tubuh \\
\hline & Semoga & lahir & lah & $\begin{array}{l}\text { anak lakı } \\
\text { - laki }\end{array}$ & lah & lahir \\
\hline & an & $\begin{array}{l}\text { boru } \\
\text { anak p }\end{array}$ & emr & & & \\
\hline & Hasoman & nasiam & & sayur & matu & \\
\hline & Teman & kalian & & sampai & tua & \\
\hline
\end{tabular}

TL: Agar pengantin diberkati Tuhan memperoleh / melahirkan anak laki-laki dan perempuan yang bisa jadi teman sampai sayur matua.

The above data is decoded by using a combination of four translation procedures (procedures quartet) that is transposition + descriptive translation + no equivalent + modulation.

\section{SL: Sai tubuhan anakma Tubuhan boru}

\section{Hasoman nasiam sayur matua}

TL: Agar pengantin diberkati Tuhan memperoleh/melahirkan anak laki - laki

dan perempuan yang bisa jadi teman sampai sayur matua.

At TL, structural changes from SL $(\mathrm{Sai}+\mathrm{P} 1+\mathrm{S} 1+\mathrm{P} 2+$ $\mathrm{S} 2),(\mathrm{S} 1+\mathrm{S} 2+$ Ket. $)$ Became TL $(\mathrm{To}+\mathrm{S} 1+\mathrm{P} 1+\mathrm{S} 2+\mathrm{P} 2+$ $\mathrm{S} 3+$ and $\mathrm{S} 4+$ can be $+\mathrm{S} 5+$ to + Ket. $)$

Furthermore, using a procedure which is not given equivalent to the temporal interpreter cite only the original language (Simalungun). The word "sayur matua" in SL is translated as "sayur matua" in TL.

Modulation procedure is shown in the underlined sentence: SL: Sai tubuhan anakma Tubuhan boru

\section{Hasoman nasiam sayur matua}

TL: Agar pengantin diberkati Tuhan memperoleh/melahirkan anak laki - laki

dan perempuan yang bisa jadi teman sampai sayur matua.

\subsection{Result of the Research}

All data analyzed are 15 data. The researcher identifies that there are 11 data using a single procedure, 3 data using the couplet procedure and 1 data using quartet procedure. The translation is done by a translator with the procedure which can be described as follows.

Tabel 7. Presentage of Recaputalation in Translating Procedure.

\begin{tabular}{llll}
\hline No & Translating Procedure & Number & Persentage \\
\hline 1 & Single Procedure & 11 & $73,3 \%$ \\
2 & Couplet Procedure & 3 & $20,0 \%$ \\
3 & Quartet Procedure & 1 & $6,7 \%$ \\
& Total & 15 & $100 \%$ \\
\hline
\end{tabular}

From the results mentioned above, it can be understood that the procedures used by the translator to translate the text of Makhioui in Wedding Ceremony in Simalungun consist of 3 translation procedures that is 1) single procedure, 2) couplet procedure, and 3) quartet procedure. The results show that a single procedure is more compared with other 
procedures. The comparison can be seen in the following table.

Table 8. Comparison of Single and Double Procedures.

\begin{tabular}{llll}
\hline No & Translating Procedure & Number & Persentage \\
\hline 1 & Single Procedure & 11 & $73,3 \%$ \\
2 & Dauble Procedure & 4 & $26,7 \%$ \\
& Jumlah & 15 & $100 \%$ \\
\hline
\end{tabular}

\subsection{Quality of the Translation}

The quality of the translation in the translated text of wedding ceremony Makhioui in Simalungun to Indonesian language is summarized in Table 10 below.

Table 9. Quality of the Translation.

\begin{tabular}{llll}
\hline No & element of quality & number & Persentage \\
\hline 1. & accuracy & 7 & $46,6 \%$ \\
2. & acceptance & 9 & $60 \%$ \\
3. & Readability & 8 & $53,3 \%$ \\
& total & 24 & $100 \%$ \\
\hline
\end{tabular}

A. The Accuracy Level of Message

Data source in this study is 15 . Of these, 7 data are an accurate translation, 8 data are including inaccurate translation. Target data included in the second category are described below.

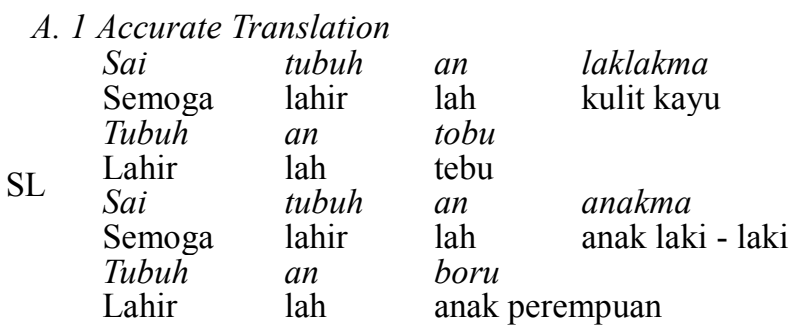

TL: Agar pengantin diberkati Tuhan memperoleh / melahirkan anak laki- laki

dan perempuan.

The above data is translated using the procedure transposition + modulation (couplet procedures couplets), and relatively accurate because it does not create a distorted meaning.

\section{A.2 Less Accurate Translation}

Data are classified as less accurate:

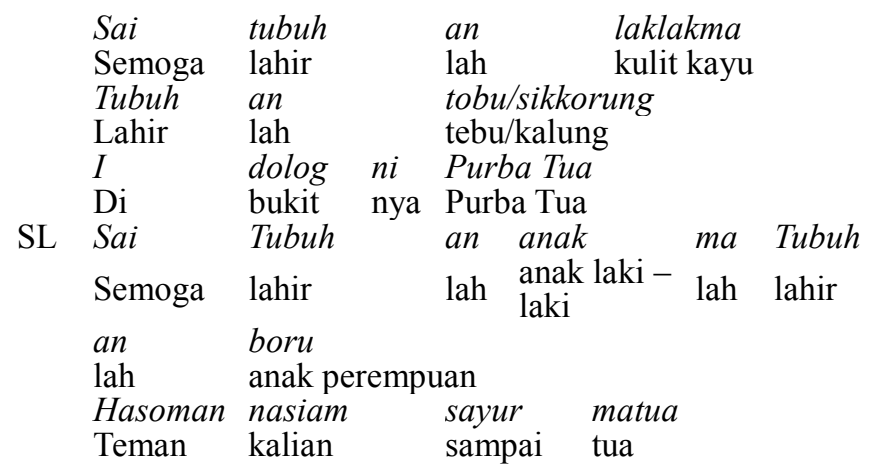

TL: Agar pengantin diberkati Tuhan memperoleh / melahirkan anak laki-laki dan perempuan yang bisa jadi teman sampai sayur matua.

The above data are decoded by using a combination of four translation procedures (quartet procedures ).

The above data is classified as less accurate because there is an untranslated phrase eg. "sayur matua".

The level of the acceptability of translation

B.1 The Acceptability of Translation

$\begin{array}{lllll} & \text { Sai } & \text { tubuh } & \text { an } & \text { laklakma } \\ & \text { Semoga } & \text { lahir } & \text { lah } & \text { kulit kayu } \\ & \text { Tubuh } & \text { an } & \text { tobu } & \\ \text { SL } & \text { Lahir } & \text { lah } & \text { tebu } & \\ & \text { Sai } & \text { tubuh } & \text { an } & \text { anakma } \\ & \text { Semoga } & \text { lahir } & \text { lah } & \text { anak laki - laki } \\ & \text { Tubuh } & \text { an } & \text { boru } & \\ \text { Lahir } & \text { lah } & \text { anak perempuan }\end{array}$

TL: Agar pengantin diberkati Tuhan memperoleh / melahirkan anak laki- laki

dan perempuan.

B.2 Less Acceptabile Translation

There are as many as 5 data is classified as a translation less acceptable:

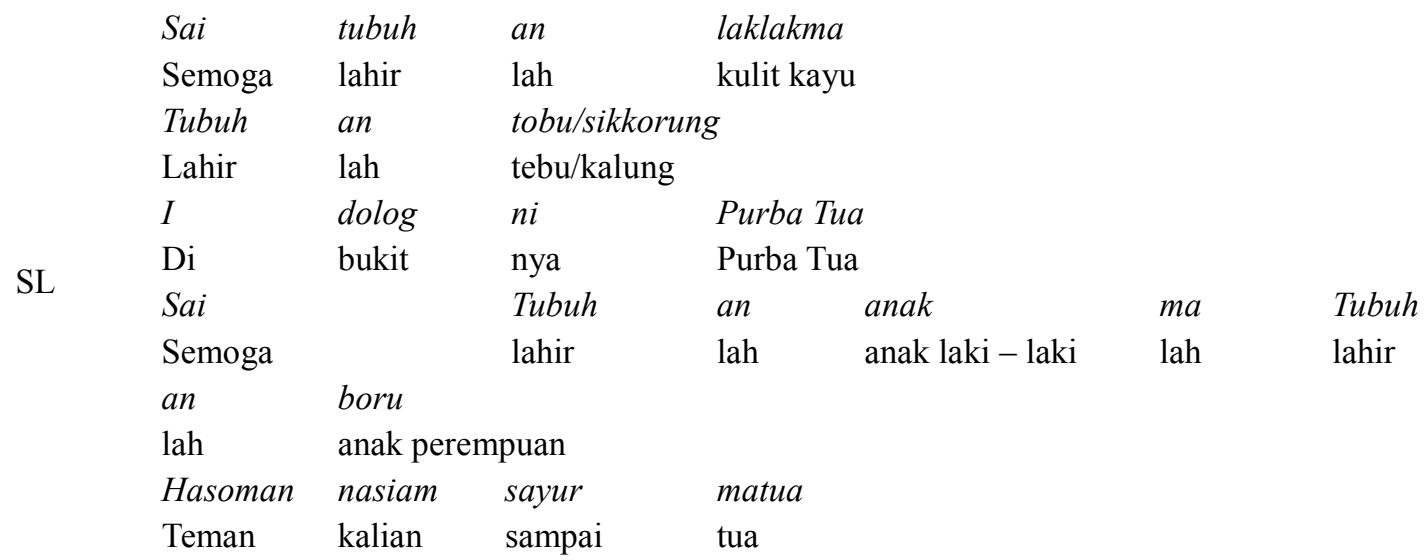

TL: Agar pengantin diberkati Tuhan memperoleh / melahirkan anak laki-laki dan perempuan yang bisa jadi teman sampai sayur matua.

B. Readability of Translation
C.1 High Readability of Translation

This study identifies as many as 8 data that belongs to this category, namely: 


$\begin{array}{lll}\text { Bittang na } & \text { rumiris } \\ \text { Bintang yang } & \text { banyak } \\ \text { Ombun na } & \text { sumorop } \\ \text { SL } & \text { Embun yang } & \text { banyak } \\ \text { Anak } & \text { pe riris } \\ \text { Anak laki - laki } & \text { pun banyak } \\ \text { Boru } & \text { pe torop } \\ \text { Anak perempuan } & \text { pun banyak }\end{array}$

TL: Agar pengantin diberkati Tuhan memperoleh keturunan laki-laki dan perempuan yang banyak.

C.2 Medium Readability of Translation

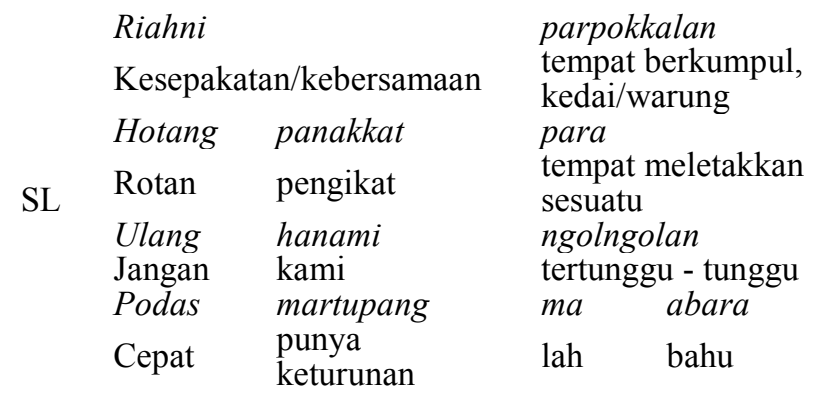

TL: Agar pengantin cepat diberkati Tuhan memperoleh keturunan, jangan sampai orangtua (tondong) lama menanti.

\section{Conclusion}

It has been explained that the aim of this study is to formulate a translation procedure applied in translating umpasa / poem contained in the text Makhioui at the wedding ceremony of the Simalungun language into Indonesia language and assess the impact of the translation procedures on the quality of the translation. From the data analysis, it can be concluded as follows:

a Translators in translating umpasa without sampiran of the fifteenth umpasa presented in text Makhioui in wedding ceremony.

b Sampiran only sustains the contents of Umpasa as a good rhyme. It should be a good philosophical relationship between sampiran and content.

c The purpose of the Makhioui translator translates text on a traditional wedding party from Simalungun language into Indonesia language in such a way that the book can be used by many people.

\section{References}

[1] Ainon Muhammad. 1994. Panduan Menterjemah, Dewan Bahasa dan Pustaka, Kementerian Pendidikan Malaysia.

[2] Ainon Mohd dan Abdullah Hasan. 2005. Teori dan Tehnik Terjemahan. Edisi ketiga Kuala Lumpur: PTS Publication \& Distributors Sdn. Bhd.

[3] Baker, M. 1992. In Other Words: A Coursebook on translation. London: Sage Publication.

[4] Basnett McGuire. 1980. Translation Studies. New York: Mathuen \& Co Ltd.
[5] Bassnett, Susan dan André Lefevere (Eds.). 1995. Translation, History and Culture. USA: Cassell.

[6] Bassnett, Susan. 2002. Translation Studies $3^{\text {rd }}$ edition. London and New York: Routledge.

[7] Bell, Roger T. 1991. Translation and Translating: Theory and Practice. London: Longman.

[8] Brislin, R. W. 1976. Translation: Application and Research. New York: Garden Press, Inc.

[9] Catford, J. C. 2005. Translation Shift. Dalam L. Venuti (ed.) The Translation Studies Reader. London and New York: Routledge.

[10] Choliludin. 2007. The Technique of Making Idiomatic Translation. Jakarta: Visipro.

[11] Damono, S. J. 2003. Menerjemahkan Karya Sastra. Makalah disajikan dalam Kongres Nasional Penerjemahan, di Tawangmangu, 15-16 September 2003.

[12] Dasuha. Juandarahaya dan Marthin Lukito Sinaga. 2003. Tole den Tomorlandendas Evanggelium. Sejarah Seratus Tahun Pekabaran Injil di Simalungun 2 September 1903-2003: Pematang Siantar: Kolportase GKPS.

[13] Dee Groot, A. M. B. 1997. "The Cognitif Study of Translation and Interpretation: Three Approaches". Dalam Danks et al (eds.) Cognitif Process in Translation and Interpreting. London: Sage Publication, 25-56.

[14] Dollerup, C dan Lindegard, A. 1993. Teaching Translation and Interpreting 2. Philadelphia: John Benjamins.

[15] Duff, A. 1984. The Third Language. Great Britain: Pergamon Press.

[16] Effendy, M. Ruslan. 1983. Selayang Pandang Kesusastraan Indonesia. Surabaya: PT. Bina Ilmu.

[17] Fawcett, Peter. 1998. "Strategies on Translation" in Baker. Encyclopedia of Translation Studies. London \& New York: Routledge: 107.

[18] Ghawa, John. 2006. Kebijakan dalam 1001 Pantun. Cetakan 2. Jakarta: Kompas Media Nusantara.

[19] Goodenough, W. H. 1964. Cultural Anthropology and Linguistics. In Dell Hymes (ed.). Language in Culture and Society: A Reader in Linguistics and Anthropology. New York: Harper \& Crow.

[20] Hatim, Basil \& I Mason. 1997. The Translatoras Communicator. London \& New York: Routledge.

[21] Hatim, Basil. 2001. Teaching and Researching Translation. England: Pearson Education Limited.

[22] Hatim, Basil \& Jeremy Munday. 2004. Translataion: An Advance resource Book. Guildfork, UK: University of Surrey.

[23] Hoed, Hoendoro Benny. 2006. Penerjemahan dan Kebudayaan. Dunia Pustaka Jaya. Jakarta.

[24] Hollander, J. J. de. 1995. Pedoman bahasa dan sastra Melayu / oleh J. J. de Hollander Balai Pustaka Jakarta.

[25] Jaaskelainen, R. 1997. Investigating Translation Studies. Dalam Sonja Trikkonen-Condit and John Lafting (eds): Recent Trends in Emperical Translation Research. Studies in Language 28, Joensuu: University of Joensuu, 99-120. 
[26] Koller, W. 1995. The Concept of Equivalence and the Object of translation studies. Target, 7 (2), 191-222.

[27] Krings, H. P. 1986. Translation Problems and Translation Stragegies of Advanced learners of French (L2). In House, J. and Blum-Kulka, S. (eds). Interlingual and Intercultural Communication: Discourse and Cognition in Translation. Tubingen: Narr, 267-276.

[28] Kussmaul, P. 1995. Training the Translator. Amsterdam: John Benjamins Publishing Company.

[29] Larson Mildred, L. 1984. Meaning Based Translation: A Guide to Cross- Language Equivalence. New York: Univ. Press.

[30] Lubis, Syahron. 2009. Penerjemahan Teks Mangupa Dari Bahasa Mandailing Ke Dalam Bahasa Inggris. USU: Medan.

[31] Molina, L. \& Albir, A. H. 2002. Translation Technique Revisited. A Dynamic and Functional Approach. Meta, Vol. XL Vii, No. 4, 499-512.

[32] Munday, Jeremy. 2001. Introducing Translation Studies. Theories and Application. London: Routledge.

[33] Nababan, M. R. 2004. Kecenderungan Baru dalam Studi Penerjemahan, Makalah Disajikan dalam Semiloka Penerjemahan yang diselenggarakan oleh Universitas Negeri Jogyakarta pada tanggal 23 Juli 2004.

[34] Nababan, M. R. 2003. Arah Penelitian Penerjemahan, Makalah disajikan dalam Kongres Nasional Penerjemahan, di Tawangmangu, 15-16 September 2003.

[35] Nababan, M. 2003. "Translation processes, practices, and products of professional Indonesian Translators". Unpublished Dissertation. Wellington, New Zealand: Victoria University of Wellington.

[36] Nababan, M. R. 1999. Teori Menerjemah Bahasa Inggris. Yogyakarta: Pustaka Pelajar.

[37] Newmark, Peter. 1982. A Textbook of Translation. London: Prentice Hall.

[38] Newmark, P. 1981. Approaches to Translation. Oxford: Pergamon Press.

[39] Nida, Eugene A. dan Charles R. Taber. 1982. The Theory and Practice of Translation. Leiden. E. J Brill.
[40] Nida, E. A. 1964. Towards a Science of Translating. Leiden: E. J. Brill.

[41] Pym, Anthony. 2006. Localization in the Perspective of Translation Studies: Overlap in the digital Devide. Meta. Savory, Theodore. 1969. The Art of Translation. London: Jonathan Cape. Ltd.

[42] Sathe, Vijay. 1985. Culture and Related Corporate Realities: Text, Cases, \& Reading on Organizational Entry, Establishment \& Change Irwin Series in Management and the Behavioral Sciences New York.

[43] Schein, H. Edgar. 1992. Organizational Culture and Leadership New York.

[44] Silalahi, Roswita. 2009. Dampak tehnik, Metode, dan Ideologi Penerjemah pada Kualitas Terjemahan Teks Medical Surgical Nursing dalam Bahasa Indonesia. USU: Medan.

[45] Sinaga, Salmon. 2010. Buku Uppasa pakon Uppamani Simalungun. Medan.

[46] Sinar, T. Luckman. 1981. Tuhan Sang Nahualu, Raja Siantar. Seminar Sejarah Nasional III, tanggal 12-11-1981 di Jakarta.

[47] Snell-Hornby, M. 1995. Translation Studies: An Integrated Approach. Amsterdam: John Benjamins Publishing Company.

[48] Surana. 2001. Pengantar Sastra Indonesia. Solo: PT. Tiga Serangkai Pustaka Mandiri.

[49] Suroto. 1989. Teori dan Bimbingan Apresiasi Sastra Indonesia. Jakarta: Erlangga.

[50] Suryawinata, Zuchridin \& Sugeng Hariyanto. 2003. Translation: Bahasan Teori dan Penuntun Praktis Menerjemahkan. Yogyakarta: Kanisius.

[51] Tambak., T. B. A. 1982. Sejarah Simalungun. Pematang Siantar: Yayasan Museum Simalungun.

[52] Tim Redaksi. 2008. Kamus Besar Bahasa Indonesia Pusat Bahasa. Jakarta: Gramedia dan Departemen Pendidikan Nasional.

[53] Vinay, Jean-Paul and Jean Darbelnett. 2000. A Methodology for Translation. London and New York: Rouledge. 